\title{
Targeting MicroRNAs in Cancer Gene Therapy
}

\author{
Weidan $\mathrm{Ji}^{\dagger}{ }^{\dagger}$, Bin Sun ${ }^{\dagger}$ and Changqing $\mathrm{Su}{ }^{*}$ \\ Department of Molecular Oncology, Eastern Hepatobiliary Surgery Hospital \& National Center of Liver Cancer, \\ Second Military Medical University, Shanghai 200433, China; jiweidan326@163.com (W.J.); \\ sunbin05301984@aliyun.com (B.S.) \\ * Correspondence: suchangqing@gmail.com; Tel.: +86-21-8187-5351 \\ + These authors contributed equally to this work.
}

Academic Editor: Michael Barry

Received: 18 November 2016; Accepted: 30 December 2016; Published: 9 January 2017

\begin{abstract}
MicroRNAs (miRNAs) are a kind of conserved small non-coding RNAs that participate in regulating gene expression by targeting multiple molecules. Early studies have shown that the expression of miRNAs changes significantly in different tumor tissues and cancer cell lines. It is well acknowledged that such variation is involved in almost all biological processes, including cell proliferation, mobility, survival and differentiation. Increasing experimental data indicate that miRNA dysregulation is a biomarker of several pathological conditions including cancer, and that miRNA can exert a causal role, as oncogenes or tumor suppressor genes, in different steps of the tumorigenic process. Anticancer therapies based on miRNAs are currently being developed with a goal to improve outcomes of cancer treatment. In our present study, we review the function of miRNAs in tumorigenesis and development, and discuss the latest clinical applications and strategies of therapy targeting miRNAs in cancer.
\end{abstract}

Keywords: cancer; microRNA; gene therapy; oncogene; tumor suppressor gene

\section{Introduction}

MicroRNAs (miRNAs) - a group of small endogenous non-coding functional RNAs-are approximately 18-22 nucleotides in length and widespread in plants and animals [1]. Studies have demonstrated the significance of miRNA biosynthesis and regulatory function in maintaining cellular homeostasis [2]. miRNAs are transcribed by RNA polymerase II, from initial processing to final maturing [3-5]. They are then incorporated into the RNA-induced silencing complex (RISC) together with Argonaute to silence target messenger RNA (mRNAs) usually through imperfect complementary base pairing to the $3^{\prime}$-untranslated region [6,7]. A single mRNA may possibly be targeted by multiple different miRNAs with variable efficiencies. Conversely, a single miRNA may target more than one mRNA. Through their binding to target mRNA sequences, miRNAs have various biological functions. They have an ability to inhibit or promote the expression of many related genes, which can affect several cell-signaling pathways essential to tumor development and progression, such as cell proliferation, differentiation, mobility and apoptosis [8,9]. A global reduction or increase of mature miRNAs is observed in cancer and involved in cancer biological behaviors, which has made miRNAs attractive candidates for cancer therapy.

\section{2. miRNAs and Cancer}

Carcinogenesis is a multistep process. Normal cells experience genetic changes to promote cells through pre-malignant initiation into malignant status. Microarray expression data demonstrated that the aberrant miRNA expression is a common event in cancer [10-12]. Importantly, studies featuring miRNA over-expression or ablation on mouse models demonstrated the correlations between miRNAs 
and cancer development $[13,14]$. Increasing evidence suggests that miRNAs might play a large and unanticipated role in the occurrence and development of human cancer. A study on a genome-wide basis by mapping 186 miRNAs found that miRNAs were frequently located at fragile sites, minimal regions of heterozygous loss or amplification, or common break-point regions in human cancers [15]. Besides the structural and genetic alterations, the epigenetic silencing of miRNAs genes by DNA promoter hypermethylation or histone hypoacetylation has been clarified in some solid tumors and hematological malignancies [16-18].

With the development of genomics, miRNA expression profiles between tumor tissues and normal tissues could be rapidly established through high-throughput technologies such as gene chips, real-time PCR, etc. Dysregulation of miRNA expression has been confirmed in most tumors [19,20]. The up-regulated miRNAs in tumor cells are commonly considered to be oncogenic miRNAs (oncomiRs), which can silence the tumor suppressor genes. miR-21 is a very widely studied oncomiR and has been reported at high expression levels in glioblastoma [21], pancreatic cancer [22], breast cancer [23] and colon cancer [24]. It exerts an antiapoptotic effect by targeting the tumor suppressors such as phosphatase and tensin homolog (PTEN) and programmed cell death 4 (PDCD4) [25,26]. Conversely, some miRNAs, which are often down-regulated in most cancers, can inhibit tumor progression and are termed tumor suppressor miRNAs. These miRNAs target mRNAs of some oncogenes and inhibit the carcinogenic effect by repressing the translation of oncogenic mRNAs [27]. For example, miRNAs are frequently lost in cancer, such as miR-15/miR-16 in chronic lymphocytic leukemia [20]. The miR-15a/miR-16-1 cluster can directly interact with bcl-2 mRNA and inhibit its protein translation, which induces apoptosis of leukemic cells. Loss of miR-15a/miR-16-1 results in an inhibition of leukemia cell apoptosis [28]. Tumorigenesis and development are usually associated with the down-regulation of tumor suppressive miRNAs and the up-regulation of oncomiRs.

Over-expression or down-regulation of some specific miRNAs in different tumors makes them to be potential therapeutic targets. The circulating miRNAs released from their producer cells are novel non-invasive biomarkers in cancers. Several studies detected the circulating miRNAs in cancer patients and discussed their potential relationship to the primary tumors [29]. The circulating miRNAs could be detected in body fluids (blood, urine, tears, saliva, seminal fluid, cerebrospinal fluid, and extracellular fluid) in a fairly stable form and are considered to be valuable in diagnosis and in evaluating prognosis and monitoring treatment response [30,31]. It was reported that the levels of tumor-suppressor miRNAs increased in circulation and are involved in immune responses [32]. Extracellular miRNAs released from normal or tumor cells may function as mediators of paracrine or endocrine signaling pathways among different kinds of tumor cells [33-35]. In conclusion, miRNAs may be used for clinical applications in cancer management, not only in tumor diagnosis, but in evaluating malignant potential or therapeutic efficiency, and in monitoring tumor recurrence and progression.

\section{Strategies of miRNA-Based Cancer Gene Therapy}

Intracellular miRNAs bind to the mRNAs of target genes with complementary sequences to induce mRNA degradation or inhibit mRNA translation, thereby exerting their role as post-transcriptional regulators of target genes [36]. Abnormal expression of miRNAs is closely related to cancers. For the purpose of correcting abnormal miRNA expression, miRNA-based gene therapy is becoming a new target strategy for malignant tumors [37]. During recent years, the strategies of miRNA-based tumor treatment are mainly as follows: (1) To inhibit proliferation or induce apoptosis of tumor cells by importing exogenous miRNAs, which are tumor suppressor miRNAs and down-regulated in tumor tissues. For example, the chemically synthesized miRNA mimics are used to imitate endogenous mature double-stranded miRNA with the aim to restore/enhance endogenous miRNA function [38,39]. Construction of viral vectors (adenoviral, lentiviral and retroviral vectors), which express specific miRNAs, could enhance the function of miRNAs in tumor cells; (2) To inhibit the function of miRNAs, which are oncogenic miRNAs and over-expressed in tumors, by applying the antisense oligonucleotides (ASOs) strategy, including anti-miRNA oligonucleotides (AMOs), miRNA antagomirs, 
locked-nucleic-acids antisense oligonucleotides (LNAs), miRNA sponges, multiple-target anti-miRNA antisense oligodeoxyribonucleotides (MTg-AMOs), miRNA-masking and nanoparticles [40-43]. LNAs and AMOs are the main types of ASOs that could inhibit miRNA target genes based on complementary base pairing. Antagomir-a small synthetic RNA and complementary to the specific miRNA target-is modified to make it more resistant to degradation [44,45]. Recent studies reported a tumor treatment strategy that simultaneously disturbs the function of multiple oncogenic miRNAs (miRNA sponges). This strategy used a tumor-selective replicating viral vector to mediate the expression of an artificially designed interfering long non-coding RNA (lncRNA), which comprises the binding sites of multiple oncogenic miRNAs and thus neutralizes oncogenic miRNAs in cancer cells, fully protecting the function of tumor suppressor genes and exhibiting an effective anti-tumor effect in vitro and in vivo [46,47]; (3) Artificial miRNA, designed to target single or multiple malignant tumor phenotype-related genes, provides a new therapeutic strategy for cancers $[48,49]$. The strategy used natural miRNA precursor (pre-miRNA) structures, and specifically interfered with target gene expression by replacing core sequences of pre-miRNA with complementary sequences of target genes. Artificial miRNAs have a stronger silencing effect on target genes compared with short hairpin RNAs (shRNAs); they are regulated by polymerase II promoter to achieve tissue-specific or regulatory expression. The most important feature is its high safety, low toxicity, less effect with cell endogenous RNA interfering (RNAi) and off-target [50-53].

Until now, some studies of tumor gene therapy targeting miRNA have obtained anti-tumor effects in vivo and in vitro, and laid a foundation for the safe and effective application for tumor patients (Table 1). 
Table 1. MicroRNAs (miRNAs) involved in cancers.

\begin{tabular}{|c|c|c|c|c|c|}
\hline MicroRNA & Function & Targets & Experimental Data & Therapeutic Strategy & Reference \\
\hline miR-145 & Tumor suppressor & $\begin{array}{l}\text { ROCK1, MMP11, Rab27a, } \\
\text { FSCN-1, LASP1, MTDH, SENP1, } \\
\text { E2F3, MUC13, c-Myc }\end{array}$ & $\begin{array}{l}\text { In vitro experiments in nasopharyngeal, bladder, cervical, lung, liver, breast, gastric, } \\
\text { prostate cancer cell lines } \\
\text { In vivo experiments in prostate, pancreatic, bladder cancers and multiple myeloma }\end{array}$ & $\begin{array}{l}\text { Mimics } \\
\text { Vector-based (viral) }\end{array}$ & [54-68] \\
\hline miR-34a & Tumor suppressor & $\begin{array}{l}\text { CDK6, SIRT1, E2F3, c-Met, } \\
\text { Notch, c-Myc, Fra-1, TPD52, } \\
c-S R C, \text { Bcl-2, MYCN }\end{array}$ & $\begin{array}{l}\text { In vitro experiments in neuroblastoma, glioblastoma and liver, prostate, colon, breast } \\
\text { cancer cell lines } \\
\text { In vivo experiments in multiple myeloma, glioma and prostate xenografts in mice }\end{array}$ & $\begin{array}{c}\text { Mimics } \\
\text { Vector-based (viral) }\end{array}$ & [69-80] \\
\hline $\mathrm{miR}-29 \mathrm{~b}$ & Tumor suppressor & $\begin{array}{l}\text { DNMT3A/3B, CDK6, MCL-1, } \\
\text { TCL-1, BCl-2, KDM2A, MMP2, } \\
\text { TNFAIP3/A20, BCL2L2 }\end{array}$ & $\begin{array}{l}\text { In vitro experiments in glioblastomas, acute myelocytic leukemia (AML), liver, lung, } \\
\text { gastric cancer cells } \\
\text { In vivo experiments in AML, liver and lung cancers }\end{array}$ & $\begin{array}{c}\text { Mimics } \\
\text { Vector-based (viral) }\end{array}$ & [81-90] \\
\hline Let-7a & Tumor suppressor & $\begin{array}{l}\text { K-RAS, N-RAS, CDK6, CDC25A, } \\
H M G A 2, M Y C, R T K N, E 2 F 2\end{array}$ & $\begin{array}{l}\text { In vitro experiments in lung, gastric, breast and colon cancer cells } \\
\text { In vivo experiments in breast and lung cancers }\end{array}$ & $\begin{array}{c}\text { Mimics } \\
\text { Vector-based (viral) }\end{array}$ & [91-101] \\
\hline miR-340 & Tumor suppressor & $\begin{array}{l}\text { ROCK1, MYO10, MET, CDH1, } \\
\text { NF-x03BA/B1, JAK1, EZH2 }\end{array}$ & $\begin{array}{l}\text { In vitro experiments in liver, glioma, ovarian, breast, lung cancer cells } \\
\text { In vivo experiments in liver cancer }\end{array}$ & $\begin{array}{c}\text { Mimics } \\
\text { Vector-based (viral) }\end{array}$ & [102-108] \\
\hline miR495 & Tumor suppressor & $\begin{array}{l}\text { MYB, Bim-1, MTA3, } \\
J A M-A, P R L-3\end{array}$ & $\begin{array}{l}\text { In vitro experiments in glioma, AML, lung, breast, gastric, prostate cancer cells } \\
\text { In vivo experiments in endometrial, breast, prostate cancers and leukemia }\end{array}$ & $\begin{array}{c}\text { Mimics } \\
\text { Vector-based (viral) }\end{array}$ & [109-117] \\
\hline miR155 & Oncogene & $\begin{array}{l}\text { SHIP-1, C/EBP } \beta, \text { SOCS1, SOCS6, } \\
\text { FBXW7, ZDHHC2 }\end{array}$ & $\begin{array}{l}\text { In vitro experiments in liver cancer and myeloid cells } \\
\text { In vivo experiments in pre-B lymphoma/Leukemia and liver cancer }\end{array}$ & $\begin{array}{l}\text { Antisense oligos } \\
\text { miR-MASK } \\
\text { Sponges }\end{array}$ & [118-126] \\
\hline miR-21 & Oncogene & $\begin{array}{l}\text { PDCD4, PTEN, TPM1, FOXO1, } \\
\text { Rho-B, BTG-2, Cdc25A }\end{array}$ & $\begin{array}{l}\text { In vitro experiments in multiple myeloma, glioblastoma, lung, colon, breast and liver } \\
\text { cancer cells } \\
\text { In vivo experiments in multiple myeloma }\end{array}$ & $\begin{array}{l}\text { Antisense oligos } \\
\text { miR-MASK } \\
\text { Sponges or LNA }\end{array}$ & [127-133] \\
\hline
\end{tabular}




\section{Therapy Targeting miRNAs in Human Cancers}

The potential of miRNAs as treatment targets in cancers has been explored by many studies. The therapeutics strategies either introducing tumor suppressor miRNAs or blocking oncogenic miRNAs have developed rapidly in recent years.

\subsection{Breast Cancer}

Breast cancer is a malignant disease threatening the health of women worldwide due to its high capability of recurrence and metastasis. A growing number of studies have demonstrated that miRNAs play critical roles in the development of breast cancer. Romero-Cordoba et al. found that 113 miRNAs showed higher expression and 17 miRNAs were down-regulated in breast tumors compared to the normal adjacent tissue [134]. Furthermore, differential expression of miRNAs has been tightly linked with a high incidence and mortality of breast cancer. It has been well documented that miR-892b expression is obviously down-regulated in human breast cancer specimens. Over-expression of miR-892b by its mimics in breast cancer cells significantly decreased tumor growth, metastatic capacity, and induced angiogenesis in vitro and in vivo, which was mediated by attenuating nuclear transcription factor kappa B (NF-KB) signaling pathway [135]. miR-155 is usually considered to be an oncogenic miRNA in breast cancer. miR-155 antisense oligonucleotide (miR-155 ASO) was synthetized and transfected into MDA-MB-157 cells, the cell proliferation was remarkably inhibited and cell apoptosis was increased [118]. In addition, the use of artificial miRNAs (amiRNA) provides a new strategy for breast cancer therapy. A novel amiRNA, miR p-27-5p, which targets the $3^{\prime}$-untranslated region (3'-UTR) of cyclin-dependent kinase 4 (CDK4) mRNA, was introduced into breast cancer cells. This study revealed that cell proliferation was inhibited and cell cycle was arrested through down-regulation of CDK4 expression and suppression of retinoblastoma protein (RB1) phosphorylation [136]. Liang et al. constructed an amiRNA by inserting a double-stranded miRNA gene against a C-X-C motif chemokine receptor 4 (CXCR4) into a miR-155-based RNAi expression vector, which exhibited a reduced expression level of CXCR4 and a suppressed migration and invasion in breast cancer cells [137].

\subsection{Hepatocellular Carcinoma}

Similar to other malignancies, the pathogenesis of hepatocellular carcinoma (HCC) is a complex with contribution of genetic and epigenetic changes. MiRNAs have been implicated in HCC metastasis. Zhou et al. found that miR-625 was consistently down-regulated in HCC specimens and its re-expression in HCC cells effectively suppressed cell migration and invasiveness by regulating the insulin-like growth factor 2 mRNA-binding protein 1 (IGF2BP1)/ PTEN pathway [138]. Gougelet and his colleagues used a mouse model in which $\beta$-catenin signaling was over-activated exclusively in the liver. They found that treatment with an LNA-derived inhibitor of miR-34a remarkably halved progression rates for tumors [69]. As a variety of delivery systems had been applied in HCC gene therapy, liposome-based carrier system was reported to be a potential approach. A new transferrin-targeted delivery system of negatively charged liposomes encapsulating anti-miR-221 was developed and effectively delivered anti-miR-221 to HepG2 cells, which significantly reduced the level of miR-221 [139]. Since previous studies indicated that amiRNA might be a promising therapeutic modality in gene therapy, Huang et al. constructed amiRNAs targeting firefly luciferase with the precursor frameworks of six highly abundant miRNAs in HCC. The results showed that the miR-221 precursor-based amiRNA exhibited a greatest knockdown effect on luciferase activity, indicating that construction of HCC-targeting amiRNAs by the precursor structure of miR-221 could be widely used in HCC treatment [140]. We generated an oncolytic adenoviral vector, which can specifically replicate with high copies in HCC cells, to express an artificially-designed interfering lncRNA (lncRNAi) containing the complementary binding sequences to the seed sequences of the 12 oncogenic miRNAs, including miR-21, miR-221/222, miR-224, miR-17-5p/20a, miR-10b, miR-106b, 
miR-151-5p, miR-155, miR-181a/181b, miR-184, miR-1 and miR-501-5p. The lncRNAi expressed with high level in HCC cells and competed with target genes of oncogenic miRNAs to bind to and consume those oncogenic miRNAs, thereby achieving the target anti-tumor efficacy on HCC cell line xenograft models and HCC patient-derived xenograft (PDX) models in nude mice [46].

\subsection{Lung Cancer}

Dysregulation of miRNAs contributes to lung carcinogenesis and progression. Fernandez et al. found that the expression of miR-340 was inversely correlated with progression of non-small cell lung cancer (NSCLC). Over-expression of miR-340 suppresses cell growth and induces apoptosis in NSCLC cells [108]. miRNAs are always recognized as potential targets of cancer therapy, and effective delivery strategies still need to be explored. Trang et al. and Ai et al. both reported that delivery of synthetic mimics of suppressor miRNAs in complex with a novel neutral lipid emulsion by blood stream was preferentially targeted to lung tumors and showed remarkable inhibition of tumors in a V-Ki-ras2 Kirsten rat sarcoma viral oncogene homolog (KRAS)-driven mouse models of lung cancer [141,142]. As we know, oncolytic virotherapy is a promising approach for the treatment of advanced NSCLC. Since the expression of miR-145 is lower in NSCLC cells, Li et al. constructed a new oncolytic HSV-1 (AP27i145) carrying four copies of miR-145 target sites in the $3^{\prime}$-UTR of an HSV-1 essential viral gene, infection cell protein 27 (ICP27). AP27i145 replication selectively inhibited the proliferation and neoplastic capacity of NSCLC cells. Moreover, the combination of ionizing radiation and AP27i145 infection was obviously more effective in killing cancer cells than that of monotherapy [54].

\subsection{Gastric Cancer}

Gastric cancer remains one of the most common tumors and affects human health due to its high morbidity and mortality. Studies have revealed that miRNAs are probably associated with tumorigenesis of gastric cancer [143]. Lee et al. identified miR-130a and miR-495 as oncogenic miRNA candidates, both of which are capable of targeting Runt-related transcription factor 3 (RUNX3) and can decrease apoptosis and increase cell proliferation in SNU5 and SNU484 gastric cancer cells. Furthermore, the synthetized antagomirs specific for miR-130a and miR-495 showed strong inhibitory effect on cell growth and angiogenesis [109]. Down-regulation of miR-1 has been reported in gastric cancer. Transfection of miR-1 mimics results in the suppression of cell proliferation and migration. This study provides new insights into target therapy of gastric cancer [144]. In addition, an artificial miRNA targeting liver-intestine cadherin (CDH17) via the lentivirus vector was applied to induce a long-lasting knockdown of CDH17 expression in BGC823 cells, and the CDH17-miRNA-transfected gastric cells showed a significant decrease in cell proliferation, cell motility, and migration in comparison with the control cells [145].

\subsection{Prostate Cancer}

Prostate cancer is one of the leading causes among male cancer-related deaths. Recently, miRNAs have demonstrated as critical post-transcriptional regulators of prostate cancer. Wang et al. reported that transfection of miR-221/222 mimics in prostate cancer cells could increase the activity of cell proliferation and inhibit the pro-apoptotic effect by suppressing caspase-10 [146]. Budd and his colleagues found that inhibition of miR-22 or restoration of miR-125b impaired migratory and invasive potential of prostate cancer cells in vitro [147]. Recent advances in efficient miRNA delivery techniques using prostate cancer-targeted nanoparticles offer critical information for understanding the functional role of miRNAs. Zhang et al. synthesized a polyarginine peptide (R11)-labeled non-toxic disulfidebond polyethylenimine (SS-PEI) nanocarrier for delivery of miR-145 and demonstrated that the systemic administration of R11-SSPEI/FAM-miR-145 complex dramatically inhibited tumor growth and prolonged survival time in a mouse model of intraperitoneally implanting prostate cancer xenografts, without any toxicity [55]. 


\subsection{Leukemia}

MiRNAs can function either as oncogenes or tumor suppressor genes in leukemia, and open up new opportunities for leukemia therapy. miR-126 was first validated to be a feasible therapeutic target of acute myeloid leukemia (AML). The constructed targeting nanoparticles containing antagomiR-126 can deplete the quiescent cell subpopulation and then reduce the number of leukemia stem cells [148]. Jiang et al. developed a targeted nanoparticle system, FLT3 ligand (FLT3L)-conjugated G7 poly nanosized dendriplex encapsulating miR-150, and demonstrated that the system selectively targets FLT3-overexpressing AML cells and efficiently inhibits cell viability and induces apoptosis both in vitro and in vivo [149]. Similarly, a non-viral system of transferrin (Tf)-conjugated anionic lipopolyplex nanoparticles for miR-29b mimic transfection had many advantages, such as relatively high efficiency of miRNA transfection and low cytotoxicity in AML cells [81]. Mignacca et al. reported that miRNA sponges against miR-19 and miR-155 inhibited the functions of these miRNAs and enhanced the induction of p53 and suppressor of cytokine signaling-1 (SOCS1) in human myeloma cells and mouse leukemia cells, which indicated that the antagonizing miRNA activity could reactivate the activity of cytokine-stimulated tumor suppressor pathways in leukemia cells [119].

\section{Conclusions}

As described above, there have been many new technological advances for utilizing miRNAs as therapeutic tools for cancers. The better understanding of miRNA biogenesis and function undoubtedly affects the research and development of miRNA-based therapies. Until now, several miRNAs have been validated in preclinical tests and left for further clinical investigation. In 2013, the first miRNA replacement therapy with MRX34-a liposome-formulated miR-34 mimic - entered human clinical trials for patients with advanced or metastatic liver cancer by intravenous injection [150,151]. An antagonist of miR-122 was used for hepatitis C treatment and tested in phase II clinical trials [152]. Let-7 mimic was developed to treat a variety of solid carcinomas, such as lung cancer and prostate cancer [91,92]. However, many questions regarding the miRNA-based cancer therapies remain to be overcome, including the suboptimal delivery, low bioavailability, off-target effects or long term safety. Potential employed methods may be the development of some novel miRNA-formulations including nanoparticles, polymers and virus-based approaches. Overall, reprogramming miRNA networks in cancer might constitute numerous reasonable and effective target strategies with a strong potential and chance for success in the war against cancer.

Acknowledgments: This work was supported by the projects of National Natural Science Foundation of China (81572863 to C.S., 81402565 to W.J., 81301830 to B.S.).

Conflicts of Interest: The authors declare no conflict of interest.

\section{References}

1. Bartel, D.P. MicroRNAs: Genomics, biogenesis, mechanism, and function. Cell 2004, 116, 281-297. [CrossRef]

2. Lu, J.; Getz, G.; Miska, E.A.; Alvarez-Saavedra, E.; Lamb, J.; Peck, D.; Sweet-Cordero, A.; Ebert, B.L.; Mak, R.H.; Ferrando, A.A.; et al. MicroRNA expression profiles classify human cancers. Nature 2005, 435, 834-838. [CrossRef] [PubMed]

3. Bohnsack, M.T.; Czaplinski, K.; Gorlich, D. Exportin 5 is a RanGTP-dependent dsRNA-binding protein that mediates nuclear export of pre-miRNAs. RNA 2004, 10, 185-191. [CrossRef] [PubMed]

4. Hammond, S.M.; Bernstein, E.; Beach, D.; Hannon, G.J. An RNA directed nuclease mediates post-transcriptional gene silencing in Drosophila cells. Nature 2000, 404, 293-296. [PubMed]

5. Lund, E.; Guttinger, S.; Calado, A.; Dahlberg, J.E.; Kutay, U. Nuclear export of microRNA precursors. Science 2004, 303, 95-98. [CrossRef] [PubMed]

6. Chitwood, D.H.; Timmermans, M.C. Small RNAs are on the move. Nature 2010, 467, 415-419. [CrossRef] [PubMed] 
7. Ebert, M.S.; Sharp, P.A. MicroRNA sponges: Progress and possibilities. RNA 2010, 16, 2043-2050. [CrossRef] [PubMed]

8. Budhu, A.; Ji, J.; Wang, X.W. The clinical potential of microRNAs. J. Hematol. Oncol. 2010, 3, 37. [CrossRef] [PubMed]

9. Vasudevan, S.; Tong, Y.; Steitz, J.A. Switching from repression to activation: MicroRNAs can up-regulate translation. Science 2007, 318, 1931-1934. [CrossRef] [PubMed]

10. Croce, C.M. Causes and consequences of microRNA dysregulation in cancer. Nat. Rev. Genet. 2009, 10, 704-714. [CrossRef] [PubMed]

11. Munker, R.; Calin, G.A. MicroRNA profiling in cancer. Clin. Sci (Lond.) 2011, 121, 141-158. [CrossRef] [PubMed]

12. Volinia, S.; Calin, G.A.; Liu, C.G.; Ambs, S.; Cimmino, A.; Petrocca, F.; Visone, R.; Iorio, M.; Roldo, C.; Ferracin, M.; et al. A microRNA expression signature of human solid tumors defines cancer gene targets. Proc. Natl. Acad. Sci. USA 2006, 103, 2257-2261. [CrossRef]

13. Iorio, M.V.; Croce, C.M. MicroRNA dysregulation in cancer: Diagnostics, monitoring and therapeutics. A comprehensive review. EMBO Mol. Med. 2012, 4, 143-159. [CrossRef] [PubMed]

14. Kasinski, A.L.; Slack, F.J. Epigenetics and genetics. MicroRNAs en route to the clinic: Progress in validating and targeting microRNAs for cancer therapy. Nat. Rev. Cancer 2011, 11, 849-864. [CrossRef] [PubMed]

15. Calin, G.A.; Sevignani, C.; Dumitru, C.D.; Hyslop, T.; Noch, E.; Yendamuri, S.; Shimizu, M.; Rattan, S.; Bullrich, F.; Negrini, M.; et al. Human microRNA genes are frequently located at fragile sites and genomic regions involved in cancers. Proc. Natl. Acad. Sci. USA 2004, 101, 2999-3004. [CrossRef]

16. Saito, Y.; Liang, G.; Egger, G.; Friedman, J.M.; Chuang, J.C.; Coetzee, G.A.; Jones, P.A. Specific activation of microRNAs-127 with downregulation of the proto-oncogene BCL6 by chromatin-modifying drugs in human cancer cells. Cancer Cell 2006, 9, 435-443. [CrossRef] [PubMed]

17. Lujambio, A.; Ropero, S.; Ballestar, E.; Fraga, M.F.; Cerrato, C.; Setién, F.; Casado, S.; Suarez-Gauthier, A.; Sanchez-Cespedes, M.; Git, A.; et al. Genetic unmasking of an epigenetically silenced microRNA in human cancer cells. Cancer Res. 2007, 67, 1424-1429. [CrossRef] [PubMed]

18. Hackanson, B.; Bennett, K.L.; Brena, R.M.; Jiang, J.; Claus, R.; Chen, S.S.; Blagitko-Dorfs, N.; Maharry, K.; Whitman, S.P.; Schmittgen, T.D.; et al. Epigenetic modification of CCAAT/enhancer binding protein alpha expression in acute myeloid leukemia. Cancer Res. 2008, 68, 3142-3151. [CrossRef] [PubMed]

19. Karagonlar, Z.F.; Korhan, P.; Atabey, N. Targeting c-Met in Cancer by MicroRNAs: Potential Therapeutic Applications in Hepatocellular Carcinoma. Drug Dev. Res. 2015, 76, 357-367. [CrossRef] [PubMed]

20. Calin, G.A.; Dumitru, C.D.; Shimizu, M.; Bichi, R.; Zupo, S.; Noch, E.; Aldler, H.; Rattan, S.; Keating, M.; Rai, K.; et al. Frequent deletions and down-regulation of micro-RNA genes miR15 and miR16 at 13q14 in chronic lymphocytic leukemia. Proc. Natl. Acad. Sci. USA 2002, 99, 15524-15529. [CrossRef] [PubMed]

21. Ciafrè, S.A.; Galardi, S.; Mangiola, A.; Ferracin, M.; Liu, C.G.; Sabatino, G.; Negrini, M.; Maira, G.; Croce, C.M.; Farace, M.G. Extensive modulation of a set of microRNAs in primary glioblastoma. Biochem. Biophys. Res. Commun. 2005, 334, 1351-1358. [CrossRef] [PubMed]

22. Bloomston, M.; Frankel, W.L.; Petrocca, F.; Volinia, S.; Alder, H.; Hagan, J.P.; Liu, C.G.; Bhatt, D.; Taccioli, C.; Croce, C.M. MicroRNA expression patterns to differentiate pancreatic adenocarcinoma from normal pancreas and chronic pancreatitis. JAMA 2007, 297, 1901-1908. [CrossRef] [PubMed]

23. Iorio, M.V.; Ferracin, M.; Liu, C.G.; Veronese, A.; Spizzo, R.; Sabbioni, S.; Magri, E.; Pedriali, M.; Fabbri, M.; Campiglio, M.; et al. MicroRNA gene expression deregulation in human breast cancer. Cancer Res. 2005, 65, 7065-7070. [CrossRef] [PubMed]

24. Schetter, A.J.; Leung, S.Y.; Sohn, J.J.; Zanetti, K.A.; Bowman, E.D.; Yanaihara, N.; Yuen, S.T.; Chan, T.L.; Kwong, D.L.; Au, G.K.; et al. MicroRNA expression profiles associated with prognosis and therapeutic outcome in colon adenocarcinoma. JAMA 2008, 299, 425-436. [CrossRef] [PubMed]

25. Meng, F.; Henson, R.; Wehbe-Janek, H.; Ghoshal, K.; Jacob, S.T.; Patel, T. MicroRNA-21 Regulates Expression of the PTEN Tumor Suppressor Gene in Human Hepatocellular Cancer. Gastroenterology 2007, 133, 647-658. [CrossRef] [PubMed]

26. Frankel, L.B.; Christoffersen, N.R.; Jacobsen, A.; Lindow, M.; Krogh, A.; Lund, A.H. Programmed cell death 4 (PDCD4) is an important functional target of the microRNA miR-21 in breast cancer cells. J. Biol. Chem. 2008, 283, 1026-1033. [CrossRef] [PubMed] 
27. Kumar, M.S.; Lu, J.; Mercer, K.L.; Golub, T.R.; Jacks, T. Impaired microRNA processing enhances cellular transformation and tumorigenesis. Nat. Genet. 2007, 39, 673-677. [CrossRef] [PubMed]

28. Cimmino, A.; Calin, G.A.; Fabbri, M.; Iorio, M.V.; Ferracin, M.; Shimizu, M.; Wojcik, S.E.; Aqeilan, R.I.; Zupo, S.; Dono, M.; et al. miR-15 and miR-16 induce apoptosis by targeting BCL2. Proc. Natl. Acad. Sci. USA 2005, 102, 13944-13949. [CrossRef] [PubMed]

29. Mitchell, P.S.; Parkin, R.K.; Kroh, E.M.; Fritz, B.R.; Wyman, S.K.; Pogosova-Agadjanyan, E.L.; Peterson, A.; Noteboom, J.; O’Briant, K.C.; Allen, A.; et al. Circulating microRNAs as stable blood-based markers for cancer detection. Proc. Natl. Acad. Sci. USA 2008, 105, 10513-10518. [CrossRef] [PubMed]

30. Ghai, V.; Wang, K. Recent progress toward the use of circulating microRNAs as clinical biomarkers. Arch. Toxicol. 2016, 90, 2959-2978. [CrossRef] [PubMed]

31. Singh, R.; Ramasubramanian, B.; Kanji, S.; Chakraborty, A.R.; Haque, S.J.; Chakravarti, A. Circulating microRNAs in cancer: Hope or hype? Cancer Lett. 2016, 381, 113-121. [CrossRef] [PubMed]

32. Chen, G.; Wang, J.; Cui, Q. Could circulating miRNAs contribute to cancer therapy? Trends Mol. Med. 2013, 19, 71-73. [CrossRef] [PubMed]

33. Bianchi, F.; Nicassio, F.; Marzi, M.; Belloni, E.; Dall'olio, V.; Bernard, L.; Pelosi, G.; Maisonneuve, P.; Veronesi, G.; di Fiore, P.P. A serum circulating miRNA diagnostic test to identify asymptomatic high-risk individuals with early stage lung cancer. EMBO Mol. Med. 2011, 3, 495-503. [CrossRef] [PubMed]

34. Van Schooneveld, E.; Wouters, M.C.; Van der Auwera, I.; Peeters, D.J.; Wildiers, H.; Van Dam, P.A.; Vergote, I.; Vermeulen, P.B.; Dirix, L.Y.; Van Laere, S.J. Expression profiling of cancerous and normal breast tissues identifies microRNAs that are differentially expressed in serum from patients with (metastatic) breast cancer and healthy volunteers. Breast Cancer Res. 2012, 14, R34. [CrossRef] [PubMed]

35. Moltzahn, F.; Olshen, A.B.; Baehner, L.; Peek, A.; Fong, L.; Stöppler, H.; Simko, J.; Hilton, J.F.; Carroll, P.; Blelloch, R. Microfluidic-based multiplex qRT-PCR identifies diagnostic and prognostic microRNA signatures in the sera of prostate cancer patients. Cancer Res. 2011, 71, 550-560. [CrossRef] [PubMed]

36. Maltby, S.; Plank, M.; Ptaschinski, C.; Mattes, J.; Foster, P.S. MicroRNA function in mast cell biology: Protocols to characterize and modulate microRNA expression. Methods Mol. Biol. 2015, 1220, 287-304. [PubMed]

37. Kota, J.; Chivukula, R.R.; O’Donnell, K.A.; Wentzel, E.A.; Montgomery, C.L.; Hwang, H.W.; Chang, T.C.; Vivekanandan, P.; Torbenson, M.; Clark, K.R.; et al. Therapeutic microRNA delivery suppresses tumorigenesis in a murine liver cancer model. Cell 2009, 137, 1005-1017. [CrossRef] [PubMed]

38. Bader, A.G.; Brown, D.; Winkler, M. The promise of micro-RNA replacement therapy. Cancer Res. 2010, 70, 7027-7030. [CrossRef] [PubMed]

39. Tutar, L.; Tutar, E.; Tutar, Y. MicroRNAs and cancer; an over-view. Curr. Pharm. Biotechnol. 2014, 15, 430-437. [CrossRef] [PubMed]

40. Ling, H.; Fabbri, M.; Calin, G.A. MicroRNAs and other noncoding RNAs as targets for anticancer drug development. Nat. Rev. Drug Discov. 2013, 12, 847-865. [CrossRef] [PubMed]

41. Majid, S.; Dahiya, R. MicroRNA based therapeutic strategies for cancer: Emphasis on advances in renal cell carcinoma. In MicroRNA Targeted Cancer Therapy; Sarkar, F.H., Ed.; Springer: New York, NY, USA, 2014; pp. 175-188.

42. Elmen, J.; Lindow, M.; Schutz, S.; Lawrence, M.; Petri, A.; Obad, S.; Lindholm, M.; Hedtjärn, M.; Hansen, H.F.; Berger, U.; et al. LNA-mediated microRNA silencing in non-human primates. Nature 2008, 452, 896-899. [CrossRef] [PubMed]

43. Esau, C.C. Inhibition of microRNA with antisense oligonucleotides. Methods 2008, 44, 55-60. [CrossRef] [PubMed]

44. Krutzfeldt, J.; Rajewsky, N.; Braich, R.; Rajeev, K.G.; Tuschl, T.; Manoharan, M.; Stoffel, M. Silencing of microRNAs in vivowith 'antagomirs'. Nature 2005, 438, 685-689. [CrossRef] [PubMed]

45. Czech, M.P. MicroRNAs as therapeutic targets. N. Engl. J. Med. 2006, 354, 1194-1195. [CrossRef] [PubMed]

46. Li, X.; Su, Y.; Sun, B.; Ji, W.; Peng, Z.; Xu, Y.; Wu, M.; Su, C. An artificially designed interfering lncRNA expressed by oncolytic adenovirus competitively consumes oncomiRs to exert antitumor efficacy in hepatocellular carcinoma. Mol. Cancer Ther. 2016, 15, 1436-1451. [CrossRef] [PubMed]

47. Su, Y.; Sun, B.; Lin, X.; Zhao, X.; Ji, W.; He, M.; Qian, H.; Song, X.; Yang, J.; Wang, J.; et al. Therapeutic strategy with artificially-designed i-lncRNA targeting multiple oncogenic microRNAs exhibits effective antitumor activity in diffuse large B-cell lymphoma. Oncotarget 2016, 7, 49143-49155. [CrossRef] [PubMed] 
48. Ronald, J.A.; D'Souza, A.L.; Chuang, H.Y.; Gambhir, S.S. Artificial MicroRNAs as Novel Secreted Reporters for Cell Monitoring in Living Subjects. PLoS ONE 2016, 11, e0159369. [CrossRef] [PubMed]

49. Liu, X.; Fang, H.; Chen, H.; Jiang, X.; Fang, D.; Wang, Y.; Zhu, D. An artificial miRNA against HPSE suppresses melanoma invasion properties, correlating with a down-regulation of chemokines and MAPK phosphorylation. PLoS ONE 2012, 7, e38659. [CrossRef] [PubMed]

50. Maczuga, P.; Koornneef, A.; Borel, F.; Petry, H.; van Deventer, S.; Ritsema, T.; Konstantinova, P. Optimization and comparison of knockdown efficacy between polymerase II expressed shRNA and artificial miRNA targeting luciferase and apolipoprotein B100. BMC Biotechnol. 2012, 12, 42. [CrossRef] [PubMed]

51. Boudreau, R.L.; Martins, I.; Davidson, B.L. Artificial microRNAs as siRNA shuttles: Improved safety as compared to shRNAs in vitro and in vivo. Mol. Ther. 2009, 17, 169-175. [CrossRef] [PubMed]

52. McBride, J.L.; Boudreau, R.L.; Harper, S.Q.; Staber, P.D.; Monteys, A.M.; Martins, I.; Gilmore, B.L.; Burstein, H.; Peluso, R.W.; Polisky, B.; et al. Artificial miRNAs mitigate shRNA-mediated toxicity in the brain: Implications for the therapeutic development of RNAi. Proc. Natl. Acad. Sci. USA 2008, 105, 5868-5873. [CrossRef] [PubMed]

53. Boden, D.; Pusch, O.; Silbermann, R.; Lee, F.; Tucker, L.; Ramratnam, B. Enhanced gene silencing of HIV-1 specific siRNA using microRNA designed hairpins. Nucleic Acids Res. 2004, 32, 1154-1158. [CrossRef] [PubMed]

54. Li, J.M.; Kao, K.C.; Li, L.F.; Yang, T.M.; Wu, C.P.; Horng, Y.M.; Jia, W.W.; Yang, C.T. MicroRNA-145 regulates oncolytic herpes simplex virus-1 for selective killing of human non-small cell lung cancer cells. Virol. J. 2013, 10, 241. [CrossRef] [PubMed]

55. Zhang, T.; Xue, X.; He, D.; Hsieh, J.T. A prostate cancer-targeted polyarginine-disulfide linked PEI nanocarrier for delivery of microRNA. Cancer Lett. 2015, 365, 156-165. [CrossRef] [PubMed]

56. Khan, S.; Ebeling, M.C.; Zaman, M.S.; Sikander, M.; Yallapu, M.M.; Chauhan, N.; Yacoubian, A.M.; Behrman, S.W.; Zafar, N.; Kumar, D.; et al. MicroRNA-145 targets MUC13 and suppresses growth and invasion of pancreatic cancer. Oncotarget 2014, 5, 7599-7609. [CrossRef] [PubMed]

57. Chen, Z.; Zeng, H.; Guo, Y.; Liu, P.; Pan, H.; Deng, A.; Hu, J. miRNA-145 inhibits non-small cell lung cancer cell proliferation by targeting c-Myc. J. Exp. Clin. Cancer Res. 2010. [CrossRef] [PubMed]

58. Zheng, M.; Sun, X.; Li, Y.; Zuo, W. MicroRNA-145 inhibits growth and migration of breast cancer cells through targeting oncoprotein ROCK1. Tumour Biol. 2016, 37, 8189-8196. [CrossRef] [PubMed]

59. Ding, W.; Tan, H.; Zhao, C.; Li, X.; Li, Z.; Jiang, C.; Zhang, Y.; Wang, L. miR-145 suppresses cell proliferation and motility by inhibiting ROCK1 in hepatocellular carcinoma. Tumour Biol. 2016, 37, 6255-6260. [CrossRef] [PubMed]

60. Tang, L.; Wei, D.; Yan, F. MicroRNA-145 functions as a tumor suppressor by targeting matrix metalloproteinase 11 and RabGTPase family 27a in triple-negative breast cancer. Cancer Gene Ther. 2016, 23, 258-265. [CrossRef] [PubMed]

61. Zhao, H.; Kang, X.; Xia, X.; Wo, L.; Gu, X.; Hu, Y.; Xie, X.; Chang, H.; Lou, L.; Shen, X. miR-145 suppresses breast cancer cell migration by targeting FSCN-1 and inhibiting epithelial-mesenchymal transition. Am. J. Transl. Res. 2016, 8, 3106-3114. [PubMed]

62. Wang, W.; Ji, G.; Xiao, X.; Chen, X.; Qin, W.W.; Yang, F.; Li, Y.F.; Fan, L.N.; Xi, W.J.; Huo, Y.; et al. Epigenetically regulated miR-145 suppresses colon cancer invasion and metastasis by targeting LASP1. Oncotarget 2016. [CrossRef] [PubMed]

63. Mataki, H.; Seki, N.; Mizuno, K.; Nohata, N.; Kamikawaji, K.; Kumamoto, T.; Koshizuka, K.; Goto, Y.; Inoue, H. Dual-strand tumor-suppressor microRNA-145 (miR-145-5p and miR-145-3p) coordinately targeted MTDH in lung squamous cell carcinoma. Oncotarget 2016. [CrossRef] [PubMed]

64. Inamoto, T.; Taniguchi, K.; Takahara, K.; Iwatsuki, A.; Takai, T.; Komura, K.; Yoshikawa, Y.; Uchimoto, T.; Saito, K.; Tanda, N.; et al. Intravesical administration of exogenous microRNA-145 as a therapy for mouse orthotopic human bladder cancer xenograft. Oncotarget 2015, 6, 21628-21635. [CrossRef] [PubMed]

65. Sathyanarayanan, A.; Chandrasekaran, K.S.; Karunagaran, D. MicroRNA-145 modulates epithelial-mesenchymal transition and suppresses proliferation, migration and invasion by targeting SIP1 in human cervical cancer cells. Cell Oncol. 2016. [CrossRef] [PubMed]

66. Chang, S.; Gao, L.; Yang, Y.; Tong, D.; Guo, B.; Liu, L.; Li, Z.; Song, T.; Huang, C. miR-145 mediates the antiproliferative and gene regulatory effects of vitamin D3 by directly targeting E2F3 in gastric cancer cells. Oncotarget 2015, 6, 7675-7685. [CrossRef] [PubMed] 
67. Wang, C.; Tao, W.; Ni, S.; Chen, Q.; Zhao, Z.; Ma, L.; Fu, Y.; Jiao, Z. Tumor-suppressive microRNA-145 induces growth arrest by targeting SENP1 in human prostate cancer cells. Cancer Sci. 2015, 106, 375-382. [CrossRef] [PubMed]

68. Zhang, Q.; Yan, W.; Bai, Y.; Xu, H.; Fu, C.; Zheng, W.; Zhu, Y.; Ma, J. Synthetic miR-145 mimic inhibits multiple myeloma cell growth in vitro and in vivo. Oncol. Rep. 2015, 33, 448-456. [CrossRef] [PubMed]

69. Gougelet, A.; Sartor, C.; Bachelot, L.; Godard, C.; Marchiol, C.; Renault, G.; Tores, F.; Nitschke, P.; Cavard, C.; Terris, B.; et al. Antitumour activity of an inhibitor of miR-34a in liver cancer with $\beta$-catenin-mutations. Gut 2016, 65, 1024-1034. [CrossRef] [PubMed]

70. Sun, F.; Fu, H.; Liu, Q.; Tie, Y.; Zhu, J.; Xing, R.; Sun, Z.; Zheng, X. Downregulation of CCND1 and CDK6 by miR-34a induces cell cycle arrest. FEBS. Lett. 2008, 582, 1564-1568. [CrossRef] [PubMed]

71. Yamakuchi, M.; Ferlito, M.; Lowenstein, C.J. miR-34a repression of SIRT1 regulates apoptosis. Proc. Natl. Acad. Sci. USA 2008, 105, 13421-13426. [CrossRef] [PubMed]

72. Cole, K.A.; Attiyeh, E.F.; Mosse, Y.P.; Laquaglia, M.J.; Diskin, S.J.; Brodeu, G.M.; Maris, J.M. A functional screen identifies miR-34a as a candidate neuroblastoma tumor suppressor gene. Mol. Cancer Res. 2008, 6, 735-742. [CrossRef] [PubMed]

73. Welch, C.; Chen, Y.; Stallings, R.L. MicroRNA-34a functions as a potential tumor suppressor by inducing apoptosis in neuroblastoma cells. Oncogene 2007, 26, 5017-5022. [CrossRef] [PubMed]

74. Li, N.; Fu, H.; Tie, Y.; Hu, Z.; Kong, W.; Wu, Y.; Zheng, X. miR-34a inhibits migration and invasion by down-regulation of c-Met expression in human hepatocellular carcinoma cells. Cancer Lett. 2009, 275, 44-53. [CrossRef] [PubMed]

75. Li, Y.; Guessous, F.; Zhang, Y.; Dipierro, C.; Kefas, B.; Johnson, E.; Marcinkiewicz, L.; Jiang, J.; Yang, Y.; Schmittgen, T.D.; et al. MicroRNA-34a inhibits glioblastoma growth by targeting multiple oncogenes. Cancer Res. 2009, 69, 7569-7576. [CrossRef] [PubMed]

76. Yamamura, S.; Saini, S.; Majid, S.; Hirata, H.; Ueno, K.; Deng, G.; Dahiya, R. MicroRNA-34a modulates c-Myc transcriptional complexes to suppress malignancy in human prostate cancer cells. PLoS ONE 2012, 7, e29722. [CrossRef] [PubMed]

77. Wu, J.; Wu, G.; Lv, L.; Ren, Y.F.; Zhang, X.J.; Xue, Y.F.; Li, G.; Lu, X.; Sun, Z.; Tang, K.F. MicroRNA-34a inhibits migration and invasion of colon cancer cells via targeting to Fra-1. Carcinogenesis 2012, 33, 519-528. [CrossRef] [PubMed]

78. Di Martino, M.T.; Campani, V.; Misso, G.; Gallo Cantafio, M.E.; Gullà, A.; Foresta, U.; Guzzi, P.H.; Castellano, M.; Grimaldi, A.; Gigantino, V.; et al. In vivo activity of miR-34a mimics delivered by stable nucleic acid lipid particles (SNALPs) against multiple myeloma. PLoS ONE 2014, 9, e90005. [CrossRef] [PubMed]

79. Li, G.; Yao, L.; Zhang, J.; Li, X.; Dang, S.; Zeng, K.; Zhou, Y.; Gao, F. Tumor-suppressive microRNA-34a inhibits breast cancer cell migration and invasion via targeting oncogenic TPD52. Tumour Biol. 2016, 37, 7481-7491. [CrossRef] [PubMed]

80. Adams, B.D.; Wali, V.B.; Cheng, C.J.; Inukai, S.; Booth, C.J.; Agarwal, S.; Rimm, D.L.; Győrffy, B.; Santarpia, L.; Pusztai, L.; et al. miR-34a Silences c-SRC to Attenuate Tumor Growth in Triple-Negative Breast Cancer. Cancer Res. 2016, 76, 927-939. [CrossRef] [PubMed]

81. Huang, X.; Schwind, S.; Yu, B.; Santhanam, R.; Wang, H.; Hoellerbauer, P.; Mims, A.; Klisovic, R.; Walker, A.R.; Chan, K.K.; et al. Targeted Delivery of microRNA-29b by Transferrin Conjugated Anionic Lipopolyplex Nanoparticles: A Novel Therapeutic Strategy in Acute Myeloid Leukemia. Clin. Cancer Res. 2013, 19, 2355-2367. [CrossRef] [PubMed]

82. Mott, J.L.; Kobayashi, S.; Bronk, S.F.; Gores, G.J. Mir-29 regulates Mcl-1 protein expression and apoptosis. Oncogene 2007, 26, 6133-6140. [CrossRef] [PubMed]

83. Xiong, Y.; Fang, J.H.; Yun, J.P.; Yang, J.; Zhang, Y.; Jia, W.H.; Zhuang, S.M. Effects of microRNA-29 on apoptosis, tumorigenicity, and prognosis of hepatocellular carcinoma. Hepatology 2010, 51, 836-845. [CrossRef] [PubMed]

84. Fabbri, M.; Garzon, R.; Cimmino, A.; Liu, Z.; Zanesi, N.; Callegari, E.; Liu, S.; Alder, H.; Costinean, S.; Fernandez-Cymering, C.; et al. MicroRNA-29 family reverts aberrant methylation in lung cancer by targeting DNA methyltransferases 3A and 3B. Proc. Natl. Acad. Sci. USA 2007, 104, 15805-15810. [CrossRef] [PubMed] 
85. Garzon, R.; Liu, S.; Fabbri, M.; Liu, Z.; Heaphy, C.E.; Callegari, E.; Schwind, S.; Pang, J.; Yu, J.; Muthusamy, N.; et al. MicroRNA-29b induces global DNA hypomethylation and tumor suppressor gene reexpression in acute myeloid leukemia by targeting directly DNMT3A and 3B and indirectly DNMT1. Blood 2009, 113, 6411-6418. [CrossRef] [PubMed]

86. Kong, Y.; Zou, S.; Yang, F.; Xu, X.; Bu, W.; Jia, J.; Liu, Z. RUNX3-mediated up-regulation of miR-29b suppresses the proliferation and migration of gastric cancer cells by targeting KDM2A. Cancer Lett. 2016, 381, 138-148. [CrossRef] [PubMed]

87. Langsch, S.; Baumgartner, U.; Haemmig, S.; Schlup, C.; Schäfer, S.C.; Berezowska, S.; Rieger, G.; Dorn, P.; Tschan, M.P.; Vassella, E. miR-29b Mediates NF-кB Signaling in KRAS-Induced Non-Small Cell Lung Cancers. Cancer Res. 2016, 76, 4160-4169. [CrossRef] [PubMed]

88. Zhu, K.; Liu, L.; Zhang, J.; Wang, Y.; Liang, H.; Fan, G.; Jiang, Z.; Zhang, C.Y.; Chen, X.; Zhou, G. MiR-29b suppresses the proliferation and migration of osteosarcoma cells by targeting CDK6. Protein Cell 2016, 7, 434-444. [CrossRef] [PubMed]

89. Wang, H.; Guan, X.; Tu, Y.; Zheng, S.; Long, J.; Li, S.; Qi, C.; Xie, X.; Zhang, H.; Zhang, Y. MicroRNA-29b attenuates non-small cell lung cancer metastasis by targeting matrix metalloproteinase 2 and PTEN. J. Exp. Clin. Cancer Res. 2015, 34, 59. [CrossRef] [PubMed]

90. Chung, H.J.; Choi, Y.E.; Kim, E.S.; Han, Y.H.; Park, M.J.; Bae, I.H. miR-29b attenuates tumorigenicity and stemness maintenance in human glioblastoma multiforme by directly targeting BCL2L2. Oncotarget 2015, 6, 18429-18444. [CrossRef] [PubMed]

91. Wu, X.Q.; Huang, C.; Liu, X.H.; Li, J. MicroRNAlet-7a: A novel therapeutic candidate inprostate cancer. Asian J. Androl. 2014, 16, 327-328. [PubMed]

92. Yang, G.; Zhang, W.; Yu, C.; Ren, J.; An, Z. MicroRNAlet-7: Regulation, single nucleotide polymorphism, and therapy in lung cancer. J. Cancer Res. Ther. 2015, 11, 1-6.

93. Trang, P.; Medina, P.P.; Wiggins, J.F.; Ruffino, L.; Kelnar, K.; Omotola, M.; Homer, R.; Brown, D.; Bader, A.G.; Weidhaas, J.B.; et al. Regression of murine lung tumors by the let-7 microRNA. Oncogene 2010, 29, 1580-1587. [CrossRef] [PubMed]

94. Akao, Y.; Nakagawa, Y.; Naoe, T. let-7 microRNA functions as a potential growth suppressor in human colon cancer cells. Biol. Pharm. Bull. 2006, 29, 903-906. [CrossRef] [PubMed]

95. Sampson, V.B.; Rong, N.H.; Han, J.; Yang, Q.; Aris, V.; Soteropoulos, P.; Petrelli, N.J.; Dunn, S.P.; Krueger, L.J. MicroRNA let-7a Down-regulates MYC and Reverts MYC-Induced Growth in Burkitt Lymphoma Cells. Cancer Res. 2007, 67, 9762-9770. [CrossRef] [PubMed]

96. Lee, Y.S.; Dutta, A. The tumor suppressor microRNA let-7 represses the HMGA2 oncogene. Genes Dev. 2007, 21, 1025-1030. [CrossRef] [PubMed]

97. Li, B.; Chen, P.; Chang, Y.; Qi, J.; Fu, H.; Guo, H. Let-7a inhibits tumor cell growth and metastasis by directly targeting RTKN in human colon cancer. Biochem. Biophys. Res. Commun. 2016, 478, 739-745. [CrossRef] [PubMed]

98. Zhang, Z.; Li, Y.; Huang, L.; Xiao, Q.; Chen, X.; Zhong, J.; Chen, Y.; Yang, D.; Han, Z.; Shu, Y.; et al. Let-7a suppresses macrophage infiltrations and malignant phenotype of Ewing sarcoma via STAT3/NF- $\mathrm{kB}$ positive regulatory circuit. Cancer Lett. 2016, 374, 192-201. [CrossRef] [PubMed]

99. Tang, R.; Yang, C.; Ma, X.; Wang, Y.; Luo, D.; Huang, C.; Xu, Z.; Liu, P.; Yang, L. MiR-let-7a inhibits cell proliferation, migration, and invasion by down-regulating PKM2 in gastric cancer. Oncotarget 2016, 7, 5972-5984. [PubMed]

100. Liu, K.; Zhang, C.; Li, T.; Ding, Y.; Tu, T.; Zhou, F.; Qi, W.; Chen, H.; Sun, X. Let-7a inhibits growth and migration of breast cancer cells by targeting HMGA1. Int. J. Oncol. 2015, 46, 2526-2534. [CrossRef] [PubMed]

101. Iwasaki, T.; Tanaka, K.; Kawano, M.; Itonaga, I.; Tsumura, H. Tumor-suppressive microRNA-let-7a inhibits cell proliferation via targeting of E2F2 in osteosarcoma cells. Int. J. Oncol. 2015, 46, 1543-1550. [CrossRef] [PubMed]

102. Yuan, J.; Ji, H.; Xiao, F.; Lin, Z.; Zhao, X.; Wang, Z.; Zhao, J.; Lu, J. MicroRNA-340 inhibits the proliferation and invasion of hepatocellular carcinoma cells by targeting JAK1. Biochem. Biophys. Res. Commun. 2016. [CrossRef] [PubMed]

103. Li, P.; Sun, Y.; Liu, Q. MicroRNA-340 Induces Apoptosis and Inhibits Metastasis of Ovarian Cancer Cells by Inactivation of NF-kB1. Cell. Physiol. Biochem. 2016, 38, 1915-1927. [CrossRef] [PubMed] 
104. Mohammadi-Yeganeh, S.; Paryan, M.; Arefian, E.; Vasei, M.; Ghanbarian, H.; Mahdian, R.; Karimipoor, M.; Soleimani, M. MicroRNA-340 inhibits the migration, invasion, and metastasis of breast cancer cells by targeting Wnt pathway. Tumour Biol. 2016, 37, 8993-9000. [CrossRef] [PubMed]

105. Chen, C.P.; Sun, Z.L.; Lu, X.; Wu, W.X.; Guo, W.L.; Lu, J.J.; Han, C.; Huang, J.Q.; Fang, Y. miR-340 suppresses cell migration and invasion by targeting MYO10 in breast cancer. Oncol. Rep. 2016, 35, 709-716. [CrossRef] [PubMed]

106. Yu, W.; Zhang, G.; Lu, B.; Li, J.; Wu, Z.; Ma, H.; Wang, H.; Lian, R. miR-340 impedes the progression of laryngeal squamous cell carcinoma by targeting EZH2. Gene 2016, 577, 193-201. [CrossRef] [PubMed]

107. Huang, D.; Qiu, S.; Ge, R.; He, L.; Li, M.; Li, Y.; Peng, Y. miR-340suppresses glioblastoma multiforme. Oncotarget 2015, 6, 9257-9270. [CrossRef] [PubMed]

108. Fernandez, S.; Risolino, M.; Mandia, N.; Talotta, F.; Soini, Y.; Incoronato, M.; Condorelli, G.; Banfi, S.; Verde, P. miR-340 inhibits tumor cell proliferation and induces apoptosis by targeting multiple negative regulators of p27 in non-small cell lung cancer. Oncogene 2015, 34, 3240-3250. [CrossRef] [PubMed]

109. Lee, S.H.; Jung, Y.D.; Choi, Y.S.; Lee, Y.M. Targeting of RUNX3 by miR-130a and miR-495 cooperatively increases cell proliferation and tumor angiogenesis in gastric cancer cells. Oncotarget 2015, 6, 33269-33278. [PubMed]

110. Zhang, B.; Yuan, F.; Liu, J.; Li, Y.; Zhou, F.; Liu, X.; Hao, Z.; Li, Q.; Zheng, Y.; Wang, W. Hsa-miR-495 acts as a tumor suppressor gene in glioma via the negative regulation of MYB. Mol. Med. Rep. 2016, 14, 977-982. [CrossRef] [PubMed]

111. Li, J.Z.; Wang, Z.L.; Xu, W.H.; Li, Q.; Gao, L.; Wang, Z.M. MicroRNA-495 Regulates Migration and Invasion in Prostate Cancer Cells Via Targeting Akt and mTOR Signaling. Cancer Investig. 2016, 34, 181-188. [CrossRef] [PubMed]

112. Xu, Y.Y.; Tian, J.; Hao, Q.; Yin, L.R. MicroRNA-495 downregulates FOXC1 expression to suppress cell growth and migration in endometrial cancer. Tumour Biol. 2016, 37, 239-251. [CrossRef] [PubMed]

113. Wang, L.; Liu, J.L.; Yu, L.; Liu, X.X.; Wu, H.M.; Lei, F.Y.; Wu, S.; Wang, X. Downregulated miR-495 Inhibits the G1-S Phase Transition by Targeting Bmi-1 in Breast Cancer. Medicine 2015, 94, e718. [CrossRef] [PubMed]

114. Jiang, X.; Huang, H.; Li, Z.; He, C.; Li, Y.; Chen, P.; Gurbuxani, S.; Arnovitz, S.; Hong, G.M.; Price, C.; et al. miR-495is a tumor-suppressor microRNA down-regulated in MLL-rearranged leukemia. Proc. Natl. Acad. Sci. USA 2012, 109, 19397-19402. [CrossRef] [PubMed]

115. Chu, H.; Chen, X.; Wang, H.; Du, Y.; Wang, Y.; Zang, W.; Li, P.; Li, J.; Chang, J.; Zhao, G.; et al. miR-495 regulates proliferation and migration in NSCLC by targeting MTA3. Tumour Biol. 2014, 35, 3487-3494. [CrossRef] [PubMed]

116. Cao, M.; Nie, W.; Li, J.; Zhang, Y.; Yan, X.; Guan, X.; Chen, X.; Zen, K.; Zhang, C.Y.; Jiang, X.; et al. MicroRNA-495 induces breast cancer cell migration by targeting JAM-A. Protein Cell 2014, 5, 862-872. [CrossRef] [PubMed]

117. Li, Z.; Cao, Y.; Jie, Z.; Liu, Y.; Li, Y.; Li, J.; Zhu, G.; Liu, Z.; Tu, Y.; Peng, G.; et al. miR-495 and miR-551a inhibit the migration and invasion of human gastric cancer cells by directly interacting with PRL-3. Cancer Lett. 2012, 323, 41-47. [CrossRef] [PubMed]

118. Zheng, S.R.; Guo, G.L.; Zhai, Q.; Zou, Z.Y.; Zhang, W. Effects of miR-155 antisense oligonucleotide on breast carcinoma cell line MDA-MB-157 and implanted tumors. Asian Pac. J. Cancer Prev. 2013, 14, 2361-2366. [CrossRef] [PubMed]

119. Mignacca, L.; Saint-Germain, E.; Benoit, A.; Bourdeau, V.; Moro, A.; Ferbeyre, G. Sponges against miR-19 and miR-155 reactivate the p53-Socs1 axis in hematopoietic cancers. Cytokine 2016, 82, 80-86. [CrossRef] [PubMed]

120. O'Connell, R.M.; Rao, D.S.; Chaudhuri, A.A.; Boldin, M.P.; Taganov, K.D.; Nicoll, J.; Paquette, R.L.; Baltimore, D. Sustained expression of microRNA-155 in hematopoietic stem cells causes a myeloproliferative disorder. J. Exp. Med. 2008, 205, 585-594. [CrossRef] [PubMed]

121. O'Connell, R.M.; Chaudhuri, A.A.; Rao, D.S.; Baltimore, D. Inositol phosphatase SHIP1 is a primary target of miR-155. Proc. Natl Acad. Sci. USA 2009, 106, 7113-7118. [CrossRef] [PubMed]

122. Costinean, S.; Sandhu, S.K.; Pedersen, I.M.; Tili, E.; Trotta, R.; Perrotti, D.; Ciarlariello, D.; Neviani, P.; Harb, J.; Kauffman, L.R.; et al. Src homology 2 domain-containing inositol-5-phosphatase and CCAAT enhancer-binding protein beta are targeted by miR-155 in B cells of Emicro-MiR-155 transgenic mice. Blood 2009, 114, 1374-1382. [CrossRef] [PubMed] 
123. Kluiver, J.; Poppema, S.; de Jong, D.; Blokzijl, T.; Harms, G.; Jacobs, S.; Kroesen, B.J.; van den Berg, A. BIC and miR-155 are highly expressed in Hodgkin, primary mediastinal and diffuse large B cell lymphomas. J. Pathol. 2005, 207, 243-249. [CrossRef] [PubMed]

124. Xue, X.; Liu, Y.; Wang, Y.; Meng, M.; Wang, K.; Zang, X.; Zhao, S.; Sun, X.; Cui, L.; Pan, L.; et al. miR-21 and miR-155 promote non-small cell lung cancer progression by downregulating SOCS1, SOCS6, and PTEN. Oncotarget 2016. [CrossRef] [PubMed]

125. Tang, B.; Lei, B.; Qi, G.; Liang, X.; Tang, F.; Yuan, S.; Wang, Z.; Yu, S.; He, S. microRNA-155-3p promotes hepatocellular carcinoma formation by suppressing FBXW7 expression. Exp. Clin. Cancer Res. 2016. [CrossRef] [PubMed]

126. Jiang, Y.X.; Du, Z.M.; Jiao, L.; Shao, Q.; Fu, S.; Shao, J.Y.; Zhu, X.F.; Ernberg, I.; Li, Y.H. Inhibition of miR-155 suppresses cell migration in nasopharyngeal carcinoma through targeting ZDHHC2. Int. J. Clin. Exp. Med. 2015, 8, 8472-8484. [PubMed]

127. Chan, J.A.; Krichevsky, A.M.; Kosik, K.S. MicroRNA-21 is an antiapoptotic factor in human glioblastoma cells. Cancer Res. 2005, 65, 6029-6033. [CrossRef] [PubMed]

128. Zhu, S.; Si, M.-L.; Wu, H.; Mo, Y.Y. MicroRNA-21 targets the tumor suppressor gene tropomyosin 1 (TPM1). J. Biol. Chem. 2007, 282, 14328-14336. [CrossRef] [PubMed]

129. Go, H.; Jang, J.Y.; Kim, P.J.; Kim, Y.G.; Nam, S.J.; Paik, J.H.; Kim, T.M.; Heo, D.S.; Kim, C.W.; Jeon, Y.K. MicroRNA-21 plays an oncogenic role by targeting FOXO1 and activating the PI3K/AKT pathway in diffuse large B-cell lymphoma. Oncotarget 2015, 6, 15035-15049. [CrossRef] [PubMed]

130. Najafi, Z.; Sharifi, M.; Javadi, G. Degradation of miR-21 induces apoptosis and inhibits cell proliferation in human hepatocellular carcinoma. Cancer Gene Ther. 2015, 22, 530-535. [CrossRef] [PubMed]

131. Liu, Z.L.; Wang, H.; Liu, J.; Wang, Z.X. MicroRNA-21 (miR-21) expression promotes growth, metastasis, and chemo- or radioresistance in non-small cell lung cancer cells by targeting PTEN. Mol. Cell. Biochem. 2013, 372, 35-45. [CrossRef] [PubMed]

132. Leone, E.; Morelli, E.; di Martino, M.T.; Amodio, N.; Foresta, U.; Gullà, A.; Rossi, M.; Neri, A.; Giordano, A.; Munshi, N.C.; et al. Targeting miR-21 inhibits in vitro and in vivo multiple myeloma cell growth. Clin. Cancer Res. 2013, 19, 2096-2106. [CrossRef] [PubMed]

133. Wang, P.; Zou, F.; Zhang, X.; Li, H.; Dulak, A.; Tomko, R.J., Jr.; Lazo, J.S.; Wang, Z.; Zhang, L.; Yu, J. microRNA-21 negatively regulates Cdc25A and cell cycle progression in colon cancer cells. Cancer Res. 2009, 69, 8157-8165. [CrossRef] [PubMed]

134. Romero-Cordoba, S.; Rodriguez-Cuevas, S.; Rebollar-Vega, R.; Quintanar-Jurado, V.; Maffuz-Aziz, A.; Jimenez-Sanchez, G.; Bautista-Piña, V.; Arellano-Llamas, R.; Hidalgo-Miranda, A. Identification and pathway analysis of microRNAs with no previous involvement in breast cancer. PLoS ONE 2012, 7, e31904. [CrossRef] [PubMed]

135. Jiang, L.; Yu, L.; Zhang, X.; Lei, F.; Wang, L.; Liu, X.; Wu, S.; Zhu, J.; Wu, G.; Cao, L.; et al. MiR-892b Silencing Activates NF-kB and Promotes Aggressiveness in Breast Cancer. Cancer Res. 2016, 76, 1101-1111. [CrossRef] [PubMed]

136. Tseng, C.W.; Huang, H.C.; Shih, A.C.; Chang, Y.Y.; Hsu, C.C.; Chang, J.Y.; Li, W.H.; Juan, H.F. Revealing the anti-tumor effect of artificial miRNA p-27-5p on human breast carcinoma cell line T-47D. Int. J. Mol. Sci. 2012, 13, 6352-6369. [CrossRef] [PubMed]

137. Liang, Z.; Wu, H.; Reddy, S.; Zhu, A.; Wang, S.; Blevins, D.; Yoon, Y.; Zhang, Y.; Shim, H. Blockade of invasion and metastasis of breast cancer cells via targeting CXCR4 with an artificial microRNA. Biochem. Biophys. Res. Commun. 2007, 363, 542-546. [CrossRef] [PubMed]

138. Zhou, X.; Zhang, C.Z.; Lu, S.X.; Chen, G.G.; Li, L.Z.; Liu, L.L.; Yi, C.; Fu, J.; Hu, W.; Wen, J.M.; et al. miR-625 suppresses tumour migration and invasion by targeting IGF2BP1 in hepatocellular carcinoma. Oncogene 2015, 34, 965-977. [CrossRef] [PubMed]

139. Zhang, W.; Peng, F.; Zhou, T.; Huang, Y.; Zhang, L.; Ye, P.; Lu, M.; Yang, G.; Gai, Y.; Yang, T.; et al. Targeted delivery of chemically modified anti-miR-221 to hepatocellular carcinoma with negatively charged liposomes. Int. J. Nanomed. 2015, 29, 4825-4836.

140. Huang, X.; Jia, Z. Construction of HCC-targeting artificial miRNAs using natural miRNA precursors. Exp. Ther. Med. 2013, 6, 209-215. [PubMed] 
141. Trang, P.; Wiggins, J.F.; Daige, C.L.; Cho, C.; Omotola, M.; Brown, D.; Weidhaas, J.B.; Bader, A.G.; Slack, F.J. Systemic delivery of tumor suppressor microRNA mimics using a neutral lipid emulsion inhibits lung tumors in mice. Mol. Ther. 2011, 19, 1116-1122. [CrossRef] [PubMed]

142. Ai, C.; Jiang, R.; Fu, L.; Chen, Y. MicroRNA-495 mimics delivery inhibits lung tumor progression. Tumour Biol. 2015, 36, 729-735. [CrossRef] [PubMed]

143. Zhang, M.; Du, X. Noncoding RNAs in gastric cancer: Research progress and prospects. World J. Gastroenterol. 2016, 22, 6610-6618. [CrossRef] [PubMed]

144. Han, C.; Zhou, Y.; An, Q.; Li, F.; Li, D.; Zhang, X.; Yu, Z.; Zheng, L.; Duan, Z.; Kan, Q. MicroRNA-1 (miR-1) inhibits gastric cancer cell proliferation and migration by targeting MET. Tumour Biol. 2015, 36, 6715-6723. [CrossRef] [PubMed]

145. Zhang, J.; Liu, Q.S.; Dong, W.G. Blockade of proliferation and migration of gastric cancer via targeting CDH17 with an artificial microRNA. Med. Oncol. 2011, 28, 494-501. [CrossRef] [PubMed]

146. Wang, L.; Liu, C.; Li, C.; Xue, J.; Zhao, S.; Zhan, P.; Lin, Y.; Zhang, P.; Jiang, A.; Chen, W. Effects of microRNA-221/222 on cell proliferation and apoptosis in prostate cancer cells. Gene 2015, 572, 252-258. [CrossRef] [PubMed]

147. Budd, W.T.; Seashols-Williams, S.J.; Clark, G.C.; Weaver, D.; Calvert, V.; Petricoin, E.; Dragoescu, E.A.; O'Hanlon, K.; Zehner, Z.E. Dual Action of miR-125b As a Tumor Suppressor and OncomiR-22 Promotes Prostate Cancer Tumorigenesis. PLoS ONE 2015, 10, e0142373. [CrossRef] [PubMed]

148. Dorrance, A.M.; Neviani, P.; Ferenchak, G.J.; Huang, X.; Nicolet, D.; Maharry, K.S.; Ozer, H.G.; Hoellarbauer, P.; Khalife, J.; Hill, E.B.; et al. Targeting leukemia stem cells in vivo with antagomiR-126 nanoparticles in acute myeloid leukemia. Leukemia 2015, 29, 2143-2153. [CrossRef] [PubMed]

149. Jiang, X.; Bugno, J.; Hu, C.; Yang, Y.; Herold, T.; Qi, J.; Chen, P.; Gurbuxani, S.; Arnovitz, S.; Strong, J.; et al. Eradication of Acute Myeloid Leukemia with FLT3 Ligand-Targeted miR-150 Nanoparticles. Cancer Res. 2016, 76, 4470-4480. [CrossRef] [PubMed]

150. MiRNA Therapeutics. Press Release: MiRNA Therapeutics is First to Advance MicroRNA into the Clinic for Cancer. Available online: www.mirnarx.com (accessed on 25 August 2014).

151. Beg, M.S.; Brenner, A.J.; Sachdev, J.; Borad, M.; Kang, Y.K.; Stoudemire, J.; Smith, S.; Bader, A.G.; Kim, S.; Hong, D.S. Phase I study of MRX34, a liposomalmiR-34a mimic, administered twice weekly in patients with advanced solid tumors. Investig. New Drugs 2016. [CrossRef] [PubMed]

152. Janssen, H.L.; Reesink, H.W.; Lawitz, E.J.; Zeuzem, S.; Rodriguez-Torres, M.; Patel, K.; van derMeer, A.J.; Patick, A.K.; Chen, A.; Zhou, Y.; et al. Treatment of HCV infection by targeting microRNA. N. Engl. J. Med. 2013, 368, 1685-1694. [CrossRef] [PubMed]

(C) 2017 by the authors; licensee MDPI, Basel, Switzerland. This article is an open access article distributed under the terms and conditions of the Creative Commons Attribution (CC-BY) license (http://creativecommons.org/licenses/by/4.0/). 